Jurnal Ilmu Ilmu Agribisnis: Journal of Agribusiness Science, 9(1), Februari 2021

\title{
ANALISIS PENDAPATAN DAN EFISIENSI TEKNIS USAHATANI BAWANG MERAH DI KECAMATAN GUNUNG ALIP KABUPATEN TANGGAMUS PROVINSI LAMPUNG
}

\author{
(Analysis of Income and Technical Efficiency of Shallots Farming in Gunung Alip Sub-District of \\ Tanggamus in Lampung Province)
}

Imelda Pratiwi Putri, Bustanul Arifin, dan Ktut Murniati

Jurusan Agribisnis, Fakultas Pertanian, Universitas Lampung, Jl. Prof. Dr. Soemantri Brojonegoro No. 1 Bandar Lampung 35145, e-mail : bustanul.arifin@fp.unila.ac.id

\begin{abstract}
Shallots are one of the unsubstituted agricultural commodities. The author is drawn to the onion commodity because of the many public complaints related to fluctuations in the price of shallots and their limited availability, especially on religious holidays and year-end. In addition, the availability of production factors is also often complained by farmers. Gunung Alip District is one of the districts that has the largest onion production in Tanggamus District, but its productivity is lower than that in other districts. The purpose of this study was to analyze agricultural income and technical efficiency of shallot farming in third season in Gunung Alip district, Tanggamus district. Data collection was carried out from March to April 2019. The research location was in Gunung Alip Subdistrict with the consideration that Gunung Alip Subdistrict is the area that has the largest area of harvest and onion production in Tanggamus Regency. Data collection was carried out using a questionnaire. Sampling is done by census method because all populations are sampled. The results stated that the onion farming was technically efficient. Income from cash costs and total costs obtained by farmers is IDR65,150,679.27 and IDR56,773,414.27 per hectare with R/C over cash costs 2.60 and $R / C$ over total costs 2.16 .
\end{abstract}

Key words: income, technical efficiency, shallots farming

\section{PENDAHULUAN}

Salah satu hasil pertanian dari sektor tanaman hortikultura adalah bawang merah. Penulis tertuju pada satu komoditas bawang merah karena sering dikeluhkan oleh masyarakat akan ketersediaannya dan kerap kali mengalami fluktuasi harga terutama di hari-hari besar keagamaan maupun menjelang akhir tahun. Selain itu ketersediaan faktor-faktor produksinya juga sering dikeluhkan oleh petani.

Produksi bawang merah di Indonesia masih bersifat musiman, sehingga menyebabkan kebutuhan bawang merah di luar musim panen tidak dapat dipenuhi dari produksi dalam negeri. Hal ini menyebabkan terjadinya impor bawang merah. Pada tahun 2014, Indonesia mengimpor bawang merah sebanyak 74.903 ton. Tujuan pemerintah mengimpor bawang merah untuk menjaga ketersediaan bawang merah dalam negeri dan kestabilan harga pasar (BPS 2015).

Di Indonesia bawang merah ditanam di berbagai provinsi, mulai dari Aceh sampai Papua. Rata-rata kontribusi produksi bawang merah di Indonesia tahun 2011-2015 dari Pulau Jawa yaitu sebesar 76,03 persen, sedangkan daerah luar Pulau Jawa hanya memberikan kontribusi sebesar 23,97 persen. Rendahnya kontribusi bawang merah menjadi faktor tidak terpenuhinya pasokan bawang merah di luar Pulau Jawa khususnya di Pulau Sumatera. Akibatnya permintaan semakin meningkat dan menyebabkan harga bawang merah melambung tinggi di atas harga normal (Pusdatin 2016).

Provinsi Lampung menempati urutan ke-5 sebagai penghasil bawang merah di Pulau Sumatera, namun kontribusi Provinsi Lampung masih rendah. Produksi bawang merah Provinsi Lampung pada tahun 2016, di Pulau Sumatera hanya kontribusi sebesar 2,7 persen selain itu terjadi penurunan produktivitas dari tahun 2016 ke tahun 2017 sehingga perlu adanya upaya peningkatan produksi bawang merah agar dapat memenuhi kebutuhan bawang merah di Provinsi Lampung (BPS 2018).

Kabupaten Tanggamus merupakan salah satu sentra bawang merah di Provinsi Lampung, namun produktivitas bawang merah di Kabupaten Tanggamus lebih kecil dari kabupaten lainnya. Produktivitas Kabupaten Tanggamus hanya sebesar 4,32 ton/ha sedangkan Kabupaten 
Lampung Tengah memiliki produktivitas sebesar 4,61 ton/ha (BPS 2018).

Usahatani bawang merah di Kabupaten Tanggamus terdapat di Kecamatan Kota Agung Timur, Pulau Panggung, Ulubelu, Sumberejo, Gunung Alip, Gisting, dan Pugung. Kecamatan Gunung Alip merupakan penghasil bawang merah terbesar di Kabupaten Tanggamus dengan luas panen sebesar 25 ha, produksi sebesar 450 ton dan produktivitas sebesar 18 ton/ha (BPS Kabupaten Tanggamus 2017).

Faktor-faktor produksi yang digunakan dalam usahatani bawang merah berbeda-beda dan rentan kaitannya terhadap jumlah produksi. Perbedaan penggunaan faktor-faktor produksi akan menghasilkan produksi yang berbeda pula. Selain itu karakteristik petani juga dapat menyebabkan perbedaan hasil produksi. Salah satunya umur, semakin bertambah umur petani maka tenaga akan semakin produktif dan sampai pada batas tertentu akan semakin menurun karena petani yang lebih muda biasanya akan cenderung lebih bersemangat dibandingkan dengan petani yang usianya lebih tua (Soekartawi 1988).

Berdasarkan penjelasan tersebut, maka dapat dikatakan bahwa penggunaan faktor-faktor produksi memberikan kontribusi terhadap efisiensi produksi usahatani yang sedang dijalankan, dengan demikian penelitian ini bertujuan untuk menganalisis pendapatan dan efisiensi teknis usahatani bawang merah di Kecamatan Gunung Alip Kabupaten Tanggamus Provinsi Lampung.

\section{METODE PENELITIAN}

Penelitian ini dilakukan di Kecamatan Gunung Alip Kabupaten Tanggamus. Penelitian ini hanya melakukan pengambilan data pada musim tanam ke-3 yaitu penanaman yang dilakukan pada bulan Oktober dan panen pada bulan Desember 2018. Pemilihan lokasi penelitian dilakukan secara sengaja (purposive) dengan pertimbanganbahwa daerah penelitian merupakan sentra produksi bawang merah dan memiliki luas lahan serta produksi bawang merah terbesar (BPS Kabupaten Tanggamus 2017).

Teknik pengambilan sampel yang digunakan dalam penelitian ini adalah Teknik Non Probability Sampling yang dipilih dengan Sampling Jenuh (sensus) yaitu metode penarikan sampel bila semua anggota populasi dijadikan sebagai sampel. Hal ini sering dilakukan apabila jumlah populasi kecil atau kurang dari 30 (Supriyanto dan Machfudz 2010).

Data yang digunakan dalam penelitian ini yaitu data primer dan data sekunder. Data primer diperoleh melalui wawancara dengan petani bawang merah. Data sekunder diperoleh dari berbagai instansi dan literatur baik ditingkat pusat maupun daerah. Metode analisis yang digunakan pada penelitian ini yaitu analisis pendapatan usahatani bawang merah dengan menghitung selisih antar penerimaan dengan total biaya produksi yang dikeluarkan dan analisis efisiensi teknis menggunakan aplikasi frontier 4.1 .

Pendapatan usahatani bawang merah dihitung berdasarkan pendapatan petani pada satu musim tanam. Menurut Soekartawi (2006) pendapatan usahatani secara matematis dapat dituliskan sebagai berikut:

$\pi=$ Y. Py $-\Sigma$ Xi.Pxi.

Keterangan:

$\pi=$ Pendapatan usahatani satu musim tanam (Rp)

$\mathrm{Y}=$ Jumlah produksi satu musim tanam $(\mathrm{kg})$

Py $=$ Harga bawang merah $(\mathrm{Rp} / \mathrm{kg})$

$\mathrm{X}=$ Faktor produksi usahatani bawang merah (satuan)

$\mathrm{Px}=$ Harga faktor produksi(Rp/satuan)

Kemudian untuk mengetahui perbandingan tingkat keuntungan dan biaya usahatani bawang merah di Kecamatan Gunung Alip digunakan R/C Ratio (Revenue Cost Ratio). Secara matematis dapat dituliskan sebagai berikut:

$\mathrm{R} / \mathrm{C}=\frac{\text { Revenue }}{\text { Cost }}$

Jika R/C > 1 maka dapat dikatakan usahatani bawang merah menguntungkan, sedangkan jika $\mathrm{R} / \mathrm{C}<1$ maka usahatani bawang merah rugi.

Data penelitian ini dianalisis secara kuantitatif dengan analisis efisiensi teknis dan faktor-faktor yang mempengaruhi inefisiensi teknis. Model fungsi produksi stochastic frontier untuk usahatani bawang merah di Kecamatan Gunung Alip Kabupaten Tanggamus dengan memasukkan dua belas variabel ke dalam fungsi produksi stochastic frontier. Menurut Rahim (2012) model fungsi produksi stochastic frontier secara matematis dapat dituliskan sebagai berikut: 
$\operatorname{LnY}=\beta_{0}+\beta_{1} \operatorname{LnX} X_{1}+\beta_{2} \operatorname{LnX}{ }_{2}+\ldots+\beta_{12} \operatorname{LnX} 12+$

(vi- ui)

Keterangan:

$\mathrm{Y}=$ produksi bawang merah $(\mathrm{kg})$

$\mathrm{X}_{1} \quad$ = luas lahan bawang merah (ha)

$\mathrm{X}_{2} \quad$ = bibit bawang merah $(\mathrm{kg})$

$\mathrm{X}_{3} \quad=$ pupuk NPK Phonska $(\mathrm{kg})$

$\mathrm{X}_{4} \quad=$ pupuk urea $(\mathrm{kg})$

$\mathrm{X}_{5} \quad=$ pupuk SP $36(\mathrm{~kg})$

$\mathrm{X}_{6} \quad=$ pupuk KCL $(\mathrm{kg})$

$\mathrm{X}_{7} \quad=$ pupuk $\mathrm{ZA}(\mathrm{kg})$

$\mathrm{X}_{8} \quad=$ insektisida $(\mathrm{kg})$

$\mathrm{X}_{9} \quad$ = fungisida $(\mathrm{kg})$

$\mathrm{X}_{10} \quad=$ zat perangsang tumbuh $(\mathrm{kg})$

$\mathrm{X}_{11} \quad=$ tenaga kerja dalam keluarga (HKP)

$\mathrm{X}_{12}=$ tenaga kerja luar keluarga (HKP)

$\beta=$ koefisien regresi

$\mathrm{u} \quad=$ kesalahan (disturbance term)

(vi- ui) $=$ efek inefisiensi teknis dalam model

Analisis efisiensi teknis usahatani bawang merah di Kecamatan Gunung Alip Kabupaten Tanggamus menurut Coelli dan Battese (1988) secara matematis dapat dituliskan sebagai berikut:

$\mathrm{TE}=\frac{\mathrm{Yi}}{\mathrm{Yi} *}$

Keterangan:

$\mathrm{TE}=$ Efisiensi teknis

$\mathrm{Yi} \quad=$ Produksi aktual ke-i

$\mathrm{Yi}^{*} \quad=$ Produksi potensial/frontier ke-i

$(0 \leq \mathrm{TE} \leq 1)$

TE semakin mendekati $1=$ semakin efisien

TE semakin mendekati $0=$ semakin inefisien

Efek inefisiensi teknis merupakan faktor-faktor yang dapat menurunkan tingkat efisiensi teknis pada suatu usahatani atau faktor yang menyebabkan suatu usahatani semakin tidak efisien. Nilai parameter distribusi $\left(\mu_{\mathrm{i}}\right)$ efek inefisiensi teknis pada penelitian ini diukur menggunakan rumus sebagai berikut:

$\mathrm{U}_{\mathrm{i}}=\delta_{0}+\delta_{1} \mathrm{Z}_{1}+\delta_{2} \mathrm{Z}_{2}+\ldots+\delta_{5} \mathrm{Z}_{5}$

Keterangan:

$\mathrm{U}_{\mathrm{i}}=$ efek inefisiensi teknis

$\mathrm{Z}_{1}=$ umur petani bawang merah (tahun)

$\mathrm{Z}_{2}=$ pendidikan petani bawang merah(tahun)

$\mathrm{Z}_{3}=$ pengalaman berusahatani (tahun)

$\mathrm{Z}_{4}=$ jumlah tanggungan keluarga

$\mathrm{Z}_{5}=$ keikutsertaan dalam penyuluhan
Hasil pengukuran tersebut digolongkan sebagai berikut :

Sangat efisien $=\mathrm{TE} \geq 0,90$

Cukup efisien $=0,70 \leq \mathrm{TE}<0,90$

Belum efisien $=\mathrm{TE}<0,70$

\section{HASIL DAN PEMBAHASAN}

\section{Karakteristik Responden}

Umur petani bawang merah di Kecamatan Gunung Alipmenunjukkan bahwa hampir seluruh responden berada pada umur produktif, yaitu antara 46-55 tahun (46,67\%). Hal ini sejalan dengan penelitian Tristya (2018) yang menyatakan rata-rata umur petani bawang merah di Kecamatan Ketapang yaitu 46 tahun. Tingkat pendidikan sebagian besar petani bawang merahialah lulusan SMA sederajat $(53,34 \%)$, yang berarti bahwa petani di lokasi penelitian sudah memiliki pendidikan yang cukup baik. Jumlah tanggungan keluarga petani bawang merah ialah 4-6 orang $(56,67 \%)$.

Pengalaman berusahatani yang dimiliki oleh petani bawang merah rata-rata berkisar antara 15-20 tahun (50\%), hal ini menunjukkan bahwa petani bawang merah memiliki pengalaman yang cukup dalam berusahatani. Luas lahan garapan petani bawang merah rata-rata $0,25-0,58$ ha (50\%), dengan status kepemilikan lahan ialah sewa $(100 \%)$. Keikutsertaan dalam penyuluhan yang dilakukan petani bawang merah dikategorikan menjadi dua yaitu antara 1-2 kali dalam kategori rendah (90\%) dan antara 3-4 dalam kategori tinggi $(10 \%)$. Semakin tinggi intensitas petani dalam kegiatan penyuluhan maka semakin cepat petani tersebut menerima informasi terbaru karena penyuluhan merupakan salah satu faktor yang menentukan keberhasilan penerapan suatu adopsi inovasi (Jamal K, Kamarulzaman NH, Abdullah AM, Ismail MM, dan Hashim M, 2014).

\section{Penggunaan Input Usahatani Bawang Merah}

Penggunaan faktor produksi secara efisien merupakan upaya untuk meningkatkan produksi. Penelitian ini menganalisis sarana produksi yang digunakan selama proses budidaya tanaman bawang merah, mulai dari penanaman hingga panen yang digunakan oleh petani bawang merah di Kecamatan Gunung Alip pada musim tanam ketiga. Input yang digunakan dalam usahatani bawang merah yaitu bibit, pupuk urea, NPK 
Phonska, KCL, SP36,ZA, insektisida, fungisida, zat perangsang tumbuh, dan tenaga kerja.

Bibit merupakan salah satu input yang penting dalam kegiatan usahatani. Bibit yang digunakan oleh seluruh petani responden di Kecamatan Gunung Alip yaitu varietas bima brebes. Rata-rata penggunaan bibit bawang merah oleh petani responden di Kecamatan Gunung Alip sebesar 580,75 kilogram/ha. Penggunaan bibit belum sesuai anjuran, karena kebutuhan bibit pada usahatani bawang merah sekitar 800 sampai dengan 1.200 kilogram/ha (BPS 2013).

Pupuk yang digunakan dalam usahatani bawang merah di Kecamatan Gunung Alip yaitu pupuk NPK Phonska 278,22 kg/ha, Urea 70,42 kg/ha, ZA 245,31 kg/ha, KCL 218,69 kg/ha, dan SP36 237,09 $\mathrm{kg} / \mathrm{ha}$. Penggunaan pupuk oleh petani responden ada yang telah sesuai dan ada yang belum sesuai. Penggunaan pupuk urea dan SP 36 telah sesuai anjuran, namun penggunaan pupuk KCL, NPK, dan ZA melebihi anjuran menurut BPPTP (2016).

Obat-obatan digunakan untuk memberantas hama dan penyakit yang menyerang tanaman bawang merah. Berdasarkan penelitian, hama utama yang sering menyerang tanaman bawang merah di
Kecamatan Gunung Alip yaitu ulat grayak. Jenis pestisida yang banyak digunakan oleh petani responden yaitu Biocron, hal ini dikarenakan mudah didapatkan dan harganya relatif murah. Jenis fungisida dan zat perangsang tumbuh yang digunakan yaitu Dhitane dan Allwin Top.

Tenaga kerja pada usahatani bawang merah dimaksudkan untuk membantu petani dalam mengelola usahatani mulai dari persiapan lahan, penanaman hingga pasca panen. Penggunaan tenaga kerja oleh petani responden di Kecamatan Gunung Alip meliputi Tenaga Kerja Dalam Keluarga (TKDK) dan Tenaga Kerja Luar Keluarga (TKLK). Penggunaan tenaga kerja terbanyak oleh petani responden di Kecamatan Gunung Alip yaitu tenaga kerja luar keluarga.

\section{Analisis Pendapatan Usahatani Bawang Merah}

Rata-rata produksi bawang merah di Kecamatan Gunung Alip adalah sebesar 5.463,62 kg/ha dengan harga rata-rata Rp19.383,33/kg, sehingga penerimaan yang didapat yaitu sebesar Rp105.903.071,21.

Tabel 1. Rata-rata pendapatan usahatani bawang merah MT-III di Kecamatan Gunung Alip

\begin{tabular}{|c|c|c|c|c|c|c|c|c|}
\hline \multirow{2}{*}{ No } & \multirow{2}{*}{ Uraian } & \multicolumn{4}{|c|}{ Usahatani per 0,71 ha } & \multicolumn{2}{|c|}{ per 1 ha } & \multirow{2}{*}{$\begin{array}{c}\text { Persentase } \\
\text { biaya } \\
\text { per biaya total } \\
(\%)\end{array}$} \\
\hline & & Jumlah & Satuan & $\begin{array}{l}\text { Harga } \\
(\mathrm{Rp})\end{array}$ & Total Nilai (Rp) & Jumlah & Total Nilai (Rp) & \\
\hline 1 & Penerimaan & $3.879,17$ & $\mathrm{Kg}$ & $19.383,33$ & $75.191 .180,56$ & $5.463,62$ & $105.903 .071,21$ & \\
\hline \multirow[t]{18}{*}{2} & Biaya Produksi & & & & & & & \\
\hline & 1. Biaya Tunai & & & & & & & \\
\hline & Bibit & 412,33 & $\mathrm{Kg}$ & $24.300,00$ & $10.019 .700,00$ & 580,75 & $14.112 .253,52$ & 28,72 \\
\hline & $\begin{array}{l}\text { Pupuk NPK } \\
\text { Phonska }\end{array}$ & 197,53 & $\mathrm{Kg}$ & $2.690,00$ & $531.364,67$ & 278,22 & $748.400,94$ & 1,52 \\
\hline & Pupuk Urea & 5,00 & $\mathrm{Kg}$ & $1.833,33$ & $9.166,67$ & 7,04 & $12.910,80$ & 0,03 \\
\hline & Pupuk ZA & 174,17 & $\mathrm{Kg}$ & $2.138,46$ & $372.448,72$ & 245,31 & $524.575,66$ & 1,07 \\
\hline & Pupuk KCL & 155,27 & $\mathrm{Kg}$ & $6.793,33$ & $1.054 .778,22$ & 218,69 & $1.485 .603,13$ & 38,39 \\
\hline & Pupuk SP36 & 168,33 & $\mathrm{Kg}$ & $2.430,00$ & $409.050,00$ & 237,09 & $576.126,76$ & 1,17 \\
\hline & Obat-obatan & & & & $2.650 .190,00$ & & $3.732 .661,97$ & 7,60 \\
\hline & $\begin{array}{l}\text { TK Luar } \\
\text { Keluarga }\end{array}$ & 41,96 & HKP & $62.500,00$ & $13.887 .500,00$ & & $19.559 .859,15$ & 39,81 \\
\hline & Total Biaya Tunai & & & & $28.934 .198,27$ & & $40.752 .391,93$ & 82,95 \\
\hline & $\begin{array}{l}\text { 2. Biaya } \\
\text { diperhitungkan }\end{array}$ & & & & & & & \\
\hline & Sewa Lahan & & & & $3.169 .444,44$ & & $4.464 .006,26$ & 9,09 \\
\hline & $\begin{array}{l}\text { TK dalam } \\
\text { Keluarga }\end{array}$ & 44,60 & HKP & $62.500,00$ & $2.747 .291,67$ & & $3.869 .424,88$ & 7,88 \\
\hline & Penyusutan Alat & & & & $31.122,04$ & & $43.833,85$ & 0,09 \\
\hline & Total Biaya diperhitu & gkan & & & $5.947 .858,15$ & & $8.377 .265,00$ & 17,05 \\
\hline & 3. Total Biaya & & & & $34.882 .056,42$ & & $49.129 .656,93$ & \\
\hline & Pendapatan & & & & & & & \\
\hline \multirow[t]{2}{*}{3} & Pendapatan Atas Biay & Tunai & & & $46.256 .982,28$ & & $65.150 .679,27$ & \\
\hline & Pendapatan Atas Biay & Total & & & $40.309 .124,13$ & & $56.773 .414,27$ & \\
\hline \multirow[t]{2}{*}{4} & R/C Biaya Tunai & & & & 2,60 & & 2,60 & \\
\hline & R/C Biaya Total & & & & 2,16 & & 2,16 & \\
\hline
\end{tabular}


Penerimaan yang tinggi belum menjamin pendapatan yang diperoleh petani bawang merah tinggi, karena tergantung terhadap biaya produksi yang dikeluarkan, sehingga perlu adanya pengelolaan input produksi secara efektif dan efisien untuk dapat menekan biaya produksi.

Biaya tunai terbesar yang dikeluarkan dalam usahatani bawang merah adalah biaya tenaga kerja luar keluarga sebesar 47,99 persen dari total biaya tunai. Hasil penelitian menyatakan nilai $\mathrm{R} / \mathrm{C}$ atas biaya tunai sebesar 2,60 dan nilai $\mathrm{R} / \mathrm{C}$ atas biaya total sebesar 2,16.

\section{Analisis Fungsi Produksi Stochastic Frontier}

Secara matematis fungsi produksi frontier usahatani bawang merah di Kecamatan Gunung Alip Kabupaten Tanggamus adalah sebagai berikut:

$$
\begin{aligned}
\operatorname{Ln} Y f= & 7,930+0,823 \operatorname{LnX} 1+0,035 \operatorname{LnX} 2-0,030 \\
& \operatorname{LnX3}+0,007 \operatorname{LnX} 4-0,002 \operatorname{LnX} 5+ \\
& 0,027 \operatorname{LnX} 6+0,002 \operatorname{LnX} 7-0,001 \operatorname{LnX} 8 \\
& +0,028 \operatorname{LnX} 9+0,003 \operatorname{LnX} 10+0,001 \\
& \operatorname{LnX} 11+0,060 \operatorname{LnX} 12 \ldots \ldots \ldots \ldots \ldots \ldots(9)
\end{aligned}
$$

\begin{tabular}{|c|c|c|c|}
\hline Variabel & Coefficient & $\begin{array}{l}\text { Standar } \\
\text { d-error }\end{array}$ & t-ratio \\
\hline Intercep & $7,930 * * *$ & 0,650 & 12,200 \\
\hline Luas Lahan (X1) & $0,823 * * *$ & 0,086 & 9,607 \\
\hline Bibit (X2) & $0,035^{\text {ns }}$ & 0,069 & 0,511 \\
\hline $\begin{array}{l}\text { NPK Phonska } \\
\text { (X3) }\end{array}$ & $-0,030^{\mathrm{ns}}$ & 0,021 & $-1,468$ \\
\hline Urea (X4) & $0,007 * *$ & 0,003 & 2,402 \\
\hline SP 36 (X5) & $-0,002^{\mathrm{ns}}$ & 0,018 & $-0,156$ \\
\hline KCL (X6) & $0,027 *$ & 0,014 & 1,929 \\
\hline ZA (X7) & $0,002^{\text {ns }}$ & 0,003 & 1,114 \\
\hline Insektisida (X8) & $-0,001^{\text {ns }}$ & 0,003 & $-0,039$ \\
\hline Fungisida (X9) & $0,028 *$ & 0,016 & 1,780 \\
\hline Zat Perangsang & $0,003^{\text {ns }}$ & 0,004 & 0,872 \\
\hline \multicolumn{4}{|l|}{ Tumbuh (X10) } \\
\hline TKDK (X11) & $0,001^{\text {ns }}$ & 0,005 & 0,227 \\
\hline TKLK (X12) & $0,060 * * *$ & 0,010 & 6,209 \\
\hline Sigma-squared & $0,001 * * *$ & 0,000 & 3,094 \\
\hline Gamma & $0,999 * * *$ & 0,001 & 704,658 \\
\hline $\begin{array}{l}\text { Log-likelohood } \\
\text { OLS }\end{array}$ & 58,179 & & \\
\hline $\begin{array}{l}\text { Log-likelihood } \\
\text { MLE }\end{array}$ & 77,995 & & \\
\hline$L R$ & 39,633 & & \\
\hline 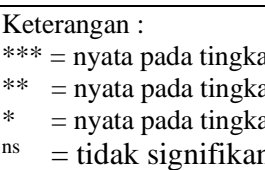 & epercayaan 90 & $\begin{array}{l}\text { Tabel }= \\
\text { Tabel }=\end{array}$ & \\
\hline
\end{tabular}

Tabel 2. Hasil pendugaan fungsi produksi stochastic frontier
Tabel 2 menjelaskan pengaruh antar variabel bebas (X) terhadap variabel terikat (Y) pada model produksi frontier yang menjelaskan bahwa variabel luas lahan, pupuk urea, pupuk KCL, fungisida, dan tenaga kerja luar keluarga berpengaruh nyata terhadap produksi bawang merah. Variabel luas lahan berpengaruh nyata terhadap produksi bawang merah pada taraf kepercayaan 99 persen. Nilai koefisien regresi yang diperoleh adalah positif yaitu 0,823 artinya semakin luas lahan yang digunakan, maka akan semakin tinggi produksi bawang merah yang dihasilkan. Hal ini berarti setiap penambahan luas lahan satu persen akan meningkatan produksi bawang merah sebesar 0,823 persen. Hasil ini sejalan dengan penelitian Andriyani (2014) yang menyatakan bahwa luas lahan berpengaruh nyataterhadap produksi bawang merah.

Variabel pupuk urea berpengaruh nyata terhadap produksi bawang merah pada taraf kepercayaan 95 persen. Nilai koefisien regresi yang diperoleh adalah positif yaitu 0,007 artinya semakin banyak jumlah pupuk urea yang digunakan, maka akan semakin tinggi produksi bawang merah yang dihasilkan. Hal ini berarti setiap penambahan pupuk urea satu persen akan meningkatan produksi bawang merah sebesar 0,007 persen.

Variabel pupuk KCL berpengaruh nyata terhadap produksi bawang merah pada taraf kepercayaan 90 persen. Nilai koefisien regresi yang diperoleh adalah positif yaitu 0,027 artinya semakin banyak jumlah pupuk KCL yang digunakan, maka akan semakin tinggi produksi bawang merah yang dihasilkan. Hal ini berarti setiap penambahan pupuk KCL satu persen akan meningkatan produksi bawang merah sebesar 0,027 persen.

Variabel fungisida berpengaruh nyata terhadap produksi bawang merah pada taraf kepercayaan 90 persen. Nilai koefisien regresi yang diperoleh adalah positif yaitu 0,028 artinya semakin banyak jumlah fungisida yang digunakan, maka akan semakin tinggi produksi bawang merah yang dihasilkan. Hal ini berarti setiap penambahan fungisida satu persen akan meningkatan produksi bawang merah sebesar 0,028 persen.

Variabel tenaga kerja luar keluarga berpengaruh nyata terhadap produksi bawang merah pada taraf kepercayaan 99 persen. Nilai koefisien regresi yang diperoleh adalah positif yaitu 0,060 artinya semakin banyak jumlah tenaga kerja luar keluarga yang digunakan, maka akan semakin tinggi produksi bawang merah yang dihasilkan. Hal ini 
berarti setiap penambahan tenaga kerja luar keluarga satu persen akan meningkatan produksi bawang merah sebesar 0,060 persen.

Tabel 2 juga menjelaskan bahwa variabel lainnya meliputi bibit, pupuk NPK, pupuk SP36, pupuk ZA, insektisida, fungisida, zat perangsang tumbuh, dan tenaga kerja dalam keluarga tidak berpengaruh nyata terhadap produksi bawang merah. Variabel bibit tidak berpengaruh nyata terhadap produksi bawang merah. Berdasarkan hasil penelitian, ratarata penggunaan bibit bawang merah oleh petani responden di Kecamatan Gunung Alip Kabupaten Tanggamus sebesar $580,75 \mathrm{~kg} / \mathrm{ha}$. Hal tersebut menunjukkan penggunaan bibit bawang merah kurang dari anjuran yaitu $800-1.200 \mathrm{~kg} / \mathrm{ha}$ (BPS 2013).

Variabel pupuk NPK Phonska tidak berpengaruh nyata terhadap produksi bawang merah. Berdasarkan hasil penelitian, rata-rata penggunaan pupuk NPK Phonska di Kecamatan Gunung Alip sebesar 278,22 kg/ha. Hal tersebut menunjukkan bahwa penggunaan pupuk NPK Phonska melebihi anjuran yaitu 200-250 kg/ha (BPPTP 2016).

Variabel pupuk ZA tidak berpengaruh nyata terhadap produksi bawang merah. Berdasarkan hasil penelitian, rata-rata penggunaan pupuk ZA di Kecamatan Gunung Alip sebesar 245,31 kg/ha. Hal tersebut menunjukkan bahwa penggunaan pupuk ZA melebihi anjuran yaitu $140-185 \mathrm{~kg} / \mathrm{ha}$ (BPPTP 2016).

Variabel tenaga kerja dalam keluarga tidak berpengaruh nyata terhadap produksi bawang merah. Hal ini sejalan dengan penelitian Chonani (2014) pada usahatani cabai merah yang menemukan bahwa variabel tenaga kerja dalam keluarga tidak berpengaruh nyata secara statistik terhadap produksi bawang merah. Berdasarkan hasil penelitian tenaga kerja dalam keluarga tidak selalu ikut serta dalam setiap proses budidaya, sehingga tidak berpengaruh nyata terhadap produksi bawang merah.

\section{Analisis Efisiensi Teknis Usahatani Bawang Merah}

Efisiensi teknis menunjukkan perbandingan antara produksi aktual yang dihasilkan petani dengan produksi potensialnya. Suatu usahatani dikatakan efisien secara teknis, jika dengan menggunakan jumlah input yang sama tetapi produksi yang dihasilkan lebih tinggi. Kategori yang digunakan dalam penelitian ini adalah sangat efisien jika memiliki nilai $\geq 0,90$, cukup efisien jika nilai 0,70 0,89, dan belum efisien < 0,70 (Coelli dan Battese, 1998).

Tabel 3 menyatakan secara individual tingkat efisiensi teknis usahatani bawang merah yang dicapai oleh masing-masing petani di Kecamatan Gunung Alip Kabupaten Tanggamus sebagian besar petani responden berada pada klasifikasi tingkat efisiensi teknis $>0,90$ yang artinya usahatani bawang merah di Kecamatan Gunung Alip sangat efisien dengan persentase sebesar 90 persen dan sisanya 10 persen berada pada klasifikasi tingkat efisiensi $0,70-0,90$ yang artinya cukup efisien.

Rata-rata efisiensi teknis usahatani bawang merah di Kecamatan Gunung Alip Kabupaten Tanggamus sebesar 0,97. Nilai efisiensi yang didapatkan menyatakan bahwa rata-rata petani responden dapat mencapai 97persen dari potensial produksi yang diperoleh. Nilai rata-rata efisiensi teknis sebesar 97 persen dimana nilai tersebut masih dibawah 100 persen artinya bahwa usahatani bawang merah di Kecamatan Gunung Alip Kabupaten Tanggamus yang dilakukan oleh petani sudah sangat efisien secara teknis dan masih terdapat peluang potensi sebesar 3,30 persen untuk meningkatkan produksi bawang merah potensialnya. Apabila nilai efisiensi teknis sudah semakin mendekati 100 persen maka semakin tinggi tingkat efisiensi teknis yang dicapai dalam usahatani.

Menurut Tajerin (2007), tingkat efisiensi yang tinggi dapat mencerminkan dua sisi. Sisi pertama, tingkat efisiensi teknis yang tinggi mencerminkan prestasi petani dalam manajerial usahatani sudah cukup baik dan berada pada level memuaskan. Sisi kedua, tingkat efisiensi teknis yang tinggi juga merefleksikan peluang yang kecil untuk meningkatkan produksi.

Tabel 3. Sebaran efisiensi teknis usahatani bawang merah di Kecamatan Gunung Alip Kabupaten Tanggamus, tahun 2019

\begin{tabular}{cccc}
\hline $\begin{array}{c}\text { Tingkat } \\
\text { Efisiensi }\end{array}$ & $\begin{array}{c}\text { Petani } \\
\text { (orang) }\end{array}$ & $\begin{array}{c}\text { Persentase } \\
(\%)\end{array}$ & $\begin{array}{c}\text { Rata }- \text { rata } \\
\text { Tingkat } \\
\text { Efisiensi } \\
\text { Teknis }\end{array}$ \\
\hline$<0,70$ & 0 & 0 & 0,97 \\
$0,70-0,90$ & 3 & 10 & \\
$>0,90$ & 27 & 90 & \\
\hline Jumlah & 30 & 100 & \\
\hline
\end{tabular}




\section{Inefisiensi Teknis Usahatani Bawang Merah}

Tingkat efisiensi teknis juga dapat dipengaruhi oleh faktor inefisiensi teknis, seperti umur, pendidikan, pengalaman berusahatani, tanggungan keluarga, dan keikutsertaan dalam penyuluhan. Faktor-faktor ini dimasukkan kedalam model karena diduga dapat mempengaruhi inefisiensi teknis. Sumber inefisiensi teknis disajikan pada Tabel 4.

Faktor umur dimasukan dalam model efek efisiensi teknis dengan dugaan dapat menurunkan inefisiensi teknis usahatani bawang merah atau usahatani semakin efisien secara teknis. Tabel 4 menunjukkan koefisien variabel umur terhadap tingkat inefisiensi teknis bernilai positif $(0,058)$ dan tidak signifikan. Hasil penelitian ini sesuai dengan penelitian Mustiko (2015) yang menyatakan bahwa faktor umur dapat meningkatkan efek inefisiensi teknis atau dengan kata lain tingkat efisiensi teknis menurun seiring bertambahnya umur petani.

Tingkat pendidikan akan mempengaruhi seseorang dalam menerima informasi dan inovasi serta mempengaruhi perilaku petani. Semakin lama pendidikan petani diduga dapat mendorong usahatanisemakin efisien.

Tabel 4 menunjukan bahwa koefisien variabel tingkat pendidikan bernilai negatif $(-0,015)$ dan tidak signifikan. Hal ini menunjukkan semakin tinggi tingkat pendidikan formal yang ditempuh petani, maka ada kecenderungan usahatani yang dijalankan semakin efisien.

Tabel 4. Hasil pendugaan faktor-faktor yang mempengaruhi inefisiensi teknis

\begin{tabular}{lrrr}
\hline \multicolumn{1}{c}{ Variabel } & Coefficient & $\begin{array}{r}\text { Standar } \\
\text { d-error }\end{array}$ & t-ratio \\
\hline Umur (Z1) & $0,058^{\text {ns }}$ & 0,079 & 0.742 \\
$\begin{array}{l}\text { Pendidikan (Z2) } \\
\text { Pengalaman }\end{array}$ & $-0,015^{\text {ns }}$ & 0,079 & -0.190 \\
$\begin{array}{l}\text { Usahatani (Z3) } \\
\text { Tanggungan }\end{array}$ & $-0,110^{* * *}$ & 0,027 & $-4,040$ \\
$\begin{array}{l}\text { Keluarga (Z4) } \\
\text { Keikutsertaan dalam } \\
\text { penyuluhan (D) }\end{array}$ & $0,060^{\text {ns }}$ & 0,086 & 0,702 \\
\hline
\end{tabular}

Keterangan :

$* * *$ = nyata pada tingkat kepercayaam $99 \%(\mathrm{t}$ Tabel $=3,0122)$

$* *$ = nyata pada tingkat kepercayaan $95 \%(\mathrm{t}$ Tabel $=2,1603)$

$* \quad=$ nyata pada tingkat kepercayaan $90 \%(\mathrm{t}$ Tabel $=1,7709)$

ns $\quad$ tidak signifikan

Pengalaman usahatani dimasukkan dalam model efek inefisiensi dengan dugaan dapat menurunkan inefisiensi teknis. Tabel 4 menunjukkan koefisien variabel pengalaman bernilai negatif $(-0,110)$ dan signifikan pada taraf kepercayaan 99 persen. Tanda negatif menunjukkan bahwa semakin lama pengalaman usahatani, maka dapat menurunkan efek inefisiensi teknis atau usahatani semakin efisien, karena petani semakin memiliki pengetahuan dalam mengelola usahatani bawang merah dengan baik. Hal ini sejalan dengan penelitian Murniati (2014) pada usahatani padi organik yang menyatakan semakin lamanya pengalaman berusahatani maka usahatani akan semakin efisien.

Tabel 4 menunjukkan bahwa koefisien variabel jumlah tanggungan keluarga terhadap tingkat inefisiensi teknis bernilai positif $(0,060)$ dan tidak signifikan. Variabel jumlah tanggungan keluarga dapat meningkatkan efek inefisiensi teknis. Hal ini menunjukkan bahwa banyaknya jumlah anggota keluarga tidak mempengaruhi tingginya tingkat efisiensi teknis, karena meskipun banyak anggota keluarga petani,belum tentu mereka mengetahui cara mengelola usahatani bawang merah, sehingga anggota keluarga yang dimiliki petani tidak membantu dalam usahatani bawang merah.

Frekuensi penyuluhan diukur berdasarkan banyaknya intensitas petani mengikuti penyuluhan tentang bawang merah dalam rentang waktu satu tahun terakhir. Penyuluhan pertanian termasuk pendidikan non formal sehingga diharapkan melalui keikutsertaan dalam penyuluhan, petani dapat mengetahui informasi, inovasi, dan mengikuti cepatnya perkembangan ilmu pengetahuan dan teknologi. Tabel 4 menunjukkan koefisien variabel keikutsertaan dalam penyuluhan terhadap tingkat inefisiensi teknis bernilai negatif $(-0,026)$ dan tidak sisgnifikan. Tanda negatif dan tidak signifikan menunjukkan bahwa semakin banyak petani mengikuti penyuluhan ada kecenderungan usahatani semakin efisien.

\section{KESIMPULAN}

Berdasarkan hasil penelitian dapat disimpulkan bahwa usahatani bawang merah di Kecamatan Gunung Alip Kabupaten Tanggamus menguntungkan. Pendapatan atas biaya tunai yang didapatkan petani pada MT-III di Kecamatan Gunung Alip sebesar Rp65.150.679,27/ha dan pendapatan atas biaya total yang diterima petani sebesar Rp56.773.414,27 dengan R/C atas biaya tunai sebesar 2,60 dan R/C atas biaya total sebesar 2,16 . Usahatani bawang merah pada musim tanam ketiga (MT-III) di Kecamatan Gunung Alip 
Kabupaten Tanggamus sudah sangat efisien secara teknis dengan rata-rata tingkat efisiensi 0,97.

\section{DAFTAR PUSTAKA}

Andriyani W. 2014. Analisis produksi dan pendapatan usahatani bawang merah lokal Tinombo di Desa Lombok Kecamatan Tinombo Kabupaten Parigi Moutong. Jurnal Agrotekbis 2(5):533-538. http://jurnal.untad. ac.id/jurnal/index.php/Agrotekbis/article/view /3659 [2 Juni 2019].

BPS [Badan Pusat Statistika]. 2015. Produksi sayuran dan buah-buahan semusim di Indonesia. https://www.bps. go.id/ publica tion/2017/10/02/9d10a13049cee1ce8aad9768/ statistik-tanaman-sayurandan-buah-buahan semusim-indonesia-2016.html [2 Juni 2019]. . 2015. Analisis tematik ST2013 subsektor efisiensi sistem produksi dan tataniaga hortikultura. Badan Pusat Statistika. Jakarta. https://docplayer. info/60201498-Badan-pusat-statistik-analisi s-tematik-st2013-subsektor-efisiensi-produk si-dan-tataniaga-hortikultura.html $\quad[10$ Juni 2019].

2018. Luas panen, produksi, dan produktivitas bawang merah menurut provinsi tahun 2017. https://www.bps.go.id/subject/55/hortikultura. html [27 Februari 2019].

BPS [Badan Pusat Statistika] Kabupaten Tanggamus. 2017. Luas panen, produksi, dan produktivitas bawang merah menurut kecamatan di Kabupaten Tanggamus tahun 2016. https://tanggamuskab.bps.go.id/sub ject/55/hortikultura.html\#subjekViewTab3

[19 Desember 2018].

Tanggamus calam ang dalam angka 2018. https://tanggamuskab.bps.go.id/publication/20 18/08/16/8c3e22c251e8f5282ce8dbc9/kabupa ten-tanggamus-dalam-angka-2018.html $\quad[10$ Juni 2019].

BPPTP [Balai Besar Pengkajian dan Pengembangan Teknologi Pertanian]. 2016. Pemupukan berimbang bawang merah. http://www.lampung.litbang.pertanian.go.id [2 Juni 2019].

Chonani SH, Prasmatiwi FE, dan Santoso H. 2014.
Efisiensi produksi dan pendapatan usahatani bawang merah di Kecamatan Metro Kibang Kabupaten Lampung Timur : pendekatan fungsi produksi frontier. Jurnal Ilmu Ilmu Agribisnis, 2(2):95-102. http://jurna.fp.unila.ac.id/index.php/JIA/articl e/view/730/672 [18 September 2019]

Coelli T, Rao DSP, dan Battese GE. 1998. An introduction to efficiency and productivity analysis. Kluwer Academic Publishers. Boston.

Jamal K, Kamarulzaman NH, Abdullah AM, Ismail MM, dan Hashim M. 2014. Adoptionof fragrant rice farming : the case of paddy farmers in the east coast Malaysia. $U M K$ Procedia, 1:8-17. https://www. researchgate.net/publication/273791289_Ado ption_of_Fragrant_Rice_Farming_The_Case_ of_Paddy_Farmers_in_the_East_Coast_Malay sia [18 September 2019].

Murniati K, Mulyo JH, Irham, dan Hartono S. 2014. Efisiensi teknis usahatani padi organik lahan sawah tadah hujan di Kabupaten Tanggamus. Jurnal Penelitian Pertanian Terapan, 14(1):31-38 https://jurnal.polinela. ac.id/index.php/JPPT/article/view/139 [18 September 2019].

Mustiko NI. 2015. Determinan efisiensi teknis usahatani kedelai. Jurnal Manajemen dan Agribisnis, 12. https://journal.ipb.ac.id/ index.php/jmagr/article/view/11014 [18 September 2019].

Pusdatin [Pusat Data dan Sistem Informasi Pertanian. 2016. Rata-rata Kontribusi Produksi Bawang Merah di Indonesia Tahun 2011-2015. Pusdatin. Jakarta.

Rahim A. 2012. Model Ekonometrika Perikanan Tangkap. Badan Penerbit UNM. Makassar.

Soekartawi. 1988. Prinsip Dasar Komunikasi Pertanian. Universitas Indonesia. Jakarta.

Soekartawi. 2006. Agribisnis Teori dan Aplikasi. Rajawali Press. Jakarta.

Supriyanto AS dan Machfudz M. 2010. Metodologi Riset : Manajemen Sumberdaya Manusia. UIN-Maliki Press. Malang.

Tajerin. 2007. Efisiensi teknis usaha budidaya pembesaran lele di kolam (studi kasus di Kabupaten Tulung Agung). Jurnal Ekonomi Pembangunan, 12(1):37-48. http://resposito ry.ipb.ac.id/handle/123456789/74101[18 September 2019]. 